\title{
NUTRITIONAL EVALUATION OF FORMIC ACID AND ITS SALT AND PROBIOTICS IN BROILER DIETS
}

\author{
A.I. El-Faham; M.A.M. Abdelaziz and H.A. Thabet \\ Poultry Production Department, Faculty of Agriculture, Ain Shams University, Egypt. \\ Corresponding author: Hany Thabet; E-mail: hanythabet@agr.asu.edu.eg
}

(Received 26/2/2018, accepted 25/3/2018)

\section{SUMMARY}

\begin{abstract}
$\mathrm{A}$ n experiment was conducted to determine the effect of adding formic acid (FA), sodium diformate (SDF) and probiotics [(Lactobacillus acidophilus (LA)] or Lactic acid bacteria and enzymes (LAE) to a typical corn soybean meal diets on growth performance, some blood parameters, carcass traits, ileum bacterial counts and economic efficiency of broiler chicks. A total number of 150 one-day-old Arbor Acers broiler chicks were classified into 5 equal groups, each was subdivided into 3 replicates with 10 chicks. The control group was fed basal (starter, grower and finisher) diets without supplementation (T1), while the other groups (T2: T5) were fed the basal diets supplemented with $2 \mathrm{~g}$ (SDF)/ $\mathrm{kg}$ diet (T2); $2 \mathrm{ml}$ (FA)/ $\mathrm{kg}$ diet (T3); $1 \mathrm{~g}$ (LA)/ kg diet (T4) and $1 \mathrm{~g}$ (LAE)/ kg diet (T5), respectively. Feed and water were supplied ad-libitum, throughout the whole experiment which lasted till 35 days of age. The results indicated that: Productive performance of broiler chicks; live body weight, daily weight gain, daily feed intake, feed conversion ratio, protein conversion ratio and energy conversion ratio were not affected significantly by different dietary treatments at whole experimental period, but numerically (T2 and T3) represented the best feed conversion ratio being (1.56 and 1.57), respectively, without significant differences among treatments compared with that fed control diet (1.62). Plasma total protein, albumin and uric acid were significantly different compared to control group. Carcass traits indicated that different dietary treatments (T2: T5) had no effects on carcass characteristics compared with control group. Feed additives used, in the current study tended to increase values of total bacterial count and lactic acid bacteria, but the values of coliform and salmonella counts were decreased in comparison with the control group. Economical evaluation showed that, relative economic efficiency, was improved when broiler chicks fed $2 \mathrm{~g}$ (SDF)/ $\mathrm{kg}$ diet (T2) or $2 \mathrm{ml}$ (FA)/ $\mathrm{kg}$ diet (T3) and the values were 5.49 and $4.77 \%$ more, respectively when compared with that fed control diet. It could be concluded that, supplementation of basal diets with FA or SDF enhanced productive economic efficiency of broiler chickens, without affecting carcass traits.
\end{abstract}

Key words: performance, sodium formate, formic acid, probiotic, economic efficiency.

\section{INTRODUCTION}

The selection of broilers for improved growth rate may have inadvertently resulted in changes in gastrointestinal development during growth of the bird, metabolic disorders, poor immunocompetence and increased susceptibility to pathogens (Tottori et al., 1997). Antibiotics had been considered as important additives for better growth and maintaining gut ecosystem balance for more than 50 years in poultry production (Huyghebaert et al., 2011). However, in 2006 the European Union imposed a complete ban on the use of antibiotics in poultry feeds (Singer and Hofacre, 2006; Vesna et al., 2007). As a consequence, dietary supplements, probiotics, prebiotics, symbiotic, organic acids and their salts, enzymes, herbal products and genetically modified foods have been extensively studied in search of alternatives to antibiotics (Kim et al., 2015; Das et al., 2012).

Organic acid salts have been used for decades in feed preservation, protecting food from microbial and fungal destruction or to increase the preservation effect of fermented feed, e.g. silages. Formic acid and its salts are well known to improve productivity, mineral utilization, protein digestibility, pancreatic secretion and acting against pathogens, which decreases the pressure on the animal's immune system. (Hebeler et al., 2000; Desai et al., 2007; Abdelhady et al., 2015). Several studies indicated that addition of formic acid or its 


\section{El-Faham et al.}

salts to broiler diets improved weight gain (Panda et al., 2009), increased feed consumption (Abdelaziz, 2015), improved feed efficiency (Helen and Christian, 2010), increased mineral utilization (Selle et al., 2004) and decreased total count of E. coli and Salmonella (Hebeler et al., 2000).

Probiotics are natural feed supplements and their function is based upon reducing population of harmful bacteria and decrease intestinal $\mathrm{pH}$ by an increase of volatile fatty acids production and dry matter digestibility (Makled, 1991 and Seleem et al., 2011). The most important advantage of probiotic in comparison with antibiotic is that probiotic doesn't have any residues in animal products, while antibiotics have serious consequences such as drug resistance and harmful alternative on bacterial population in the intestine (Abe et al., 1995). Many probiotic effects are mediated through balance control of proinflammatory and anti-inflammatory cytokines (Neish et al., 2000). However, probiotics can only be effective if the requirements for their growth are present in the gastrointestinal tract. Nematallah et al. (2015) reported that, prebiotic, probiotic or symbiotic supplementation at $500 \mathrm{gm} /$ ton diet seemed to be adequate to achieve the favorable results and is being recommended from the economic point of view. So, prebiotic or symbiotic are benefits compared with antibiotics for broiler chicks. Generally, the present study was carried out to investigate the effect of some organic acid salts (sodium diformate) at level of $2 \mathrm{~g} / \mathrm{kg}$ diet (formiNDF®), organic acid $2 \mathrm{ml} / \mathrm{kg}$ diet (Formic acid $\AA$ ), probiotic (Biophantase $\AA$ ) and probiotic + enzyme (Amphi-Bact ${ }^{\circledR}$ ) at the level of $1 \mathrm{~g} / \mathrm{kg}$ diet of each on productive performance, carcass characteristics, microbial profiles and the economic efficiency of broiler chickens.

\section{MATERIALS AND METHODS}

This study was carried out at the Poultry Nutrition Farm, Poultry Production Department, Faculty of Agriculture, Ain Shams University, Qalyubia, Egypt, in order to investigate the effect of formic acid, sodium diformate, Lactobacillus acidophilus and lactic acid bacteria + enzymes supplementation as growth promoting substances on growth performance, carcass characteristics, microbiological profiles and economic efficiency of broiler chickens.

\section{Experimental design and birds:}

A total number of 150 unsexed one-day-old age (Arbor Acers) broiler chicks were housed in wire floor batteries and allotted to 5 dietary treatment groups during the experimental period (0-35 days of age). Each treatment contained 3 replicates of 10 broiler chicks. The birds were weighed and placed in cages according to the average group weight. Lighting programs was $(23 \mathrm{~L}+1 \mathrm{D})$ and feed and water provided ad-libitum, during the experimental period. The composition and calculated analysis of the basal diets (starter 0-14 days, grower 15-28 days and finisher diets 29-35 days of age) are presented in Table 1. The diets were formulated based on corn-soybean to meet NRC requirements (1994).

The experimental treatments were as follow:

T1: Basal diet with no additives (control diet).

$\mathrm{T} 2: \mathrm{T} 1+$ Sodium diformate at $2 \mathrm{~g} / \mathrm{kg}$ diet (Formi-NDF® - Addcon - Germany).

T3: $\mathrm{T} 1+$ formic acid at $2 \mathrm{ml} / \mathrm{kg}$ diet (Formic acid - Sigma-Aldrish ${ }^{\circledR}$ - USA).

T4: T1 + Lactobacillus acidophilus at $1 \mathrm{~g} / \mathrm{kg}$ diet (Biophantase ${ }^{\circledR}$ - Da One Chemical - Korea), each $1.0 \mathrm{~kg}$ contains Lactobacillus plantarum 1 billion CFU, Bacillus subtilis 0.20 billion CFU and Clostridium butyricum 0.2 billion CFU.

T5: T1 + Lactic acid Bacteria and enzyme at $1 \mathrm{~g} / \mathrm{kg}$ diet (Amphi-Bact ${ }^{\circledR}$ - Ampharma - USA), each $1.0 \mathrm{~kg}$ contains $5.0 \mathrm{gm}$ Lactic acid bacteria culture (L. acidophilus $2.5 \mathrm{~g}$, L. plantarum $2.45 \mathrm{~g}$ and B. bifidum $0.05 \mathrm{~g}$ ) and 2.0 gm blended enzymes (Amylase 73\%, Cellulase 12\%, Beta-glucanase 6\% and Hemicellulase 9\%).

The prices of additives used were as follow:

T1: 0 L.E. / Ton T2: 120 L.E. / Ton, T3: 60 L.E. / Ton, T4: 60 L.E. / Ton, T5: 60 L.E. / Ton.

\section{Data collection:}

Live body weight, feed intake and mortality number for each replicate of all treatments during the experimental periods were recorded. Body weight gain, feed conversion ratio, energy and protein conversion ratio, performance index and production efficiency factor according to North and Bell (1981) and Emmert (2000) were calculated during the same periods.

\section{Blood plasma constituents:}


Individual blood samples from randomly 3 chickens of each treatment group were immediately taken during slaughtering into collecting heparinized tubes. Plasma were individually separated by centrifugation at 3000rpm for 15 minutes, transferred into a clean Eppendorf vials and stored in a deep freezer at approximately $\left(-20^{\circ} \mathrm{C}\right)$ for later analysis. Plasma constituents including total protein, albumin, creatinine, urea and uric acid were determined calorimetrically by using spectrophotometer and suitable commercial diagnostic kits.

Table (1): Feed ingredients and chemical analyses of experimental basal diets.

\begin{tabular}{lccc}
\hline \multirow{2}{*}{ Ingredient } & \multicolumn{3}{c}{ Experimental Basal Diets } \\
\cline { 2 - 4 } & Starter (0-14 days) & Grower (15-28 days) & Finisher (29-35 days) \\
\hline Yellow Corn Grains & 51.72 & 57.34 & 62.68 \\
Soy Bean Meal 44\% & 35.00 & 29.79 & 24.70 \\
Corn Gluten Meal 60\% & 5.20 & 4.90 & 4.60 \\
Lime Stone $\left(\mathrm{CaCO}_{3}\right)$ & 1.35 & 1.10 & 1.08 \\
Di-Ca Phosphate & 1.90 & 1.68 & 1.55 \\
Salt $(\mathrm{NaCl})$ & 0.40 & 0.40 & 0.40 \\
Premix* & 0.30 & 0.30 & 0.30 \\
Soy Oil & 3.50 & 4.00 & 4.25 \\
DL-Methionine & 0.31 & 0.24 & 0.21 \\
Lysine - HCl & 0.32 & 0.25 & 0.23 \\
Total & 100 & 100 & 100 \\
Chemical Analysis (Calculated) & & & \\
Crude Protein \% & & 21.01 & 19.04 \\
ME Kcal/ Kg diet & 23.01 & 3159 & 3238 \\
Calcium \% & 3046 & 0.90 & 0.85 \\
Available Phosphorus \% & 1.07 & 0.45 & 0.42 \\
Lysine \% & 0.51 & 1.25 & 1.10 \\
Methionine \& Cysteine \% & 1.45 & 0.95 & 0.87 \\
Price L.E./ Ton & 1.08 & 6375 & 6335 \\
\hline
\end{tabular}

*Each $3 \mathrm{Kg}$ of premix contains: Vitamins: A: $12000000 \mathrm{IU}$; Vitamins; $D_{3} 2000000 \mathrm{IU} ; \mathrm{E}: 10000 \mathrm{mg} ; \mathrm{K}_{3}: 2000 \mathrm{mg}$; $B_{1}: 1000 \mathrm{mg} ; B_{2}: 5000 \mathrm{mg} ; B_{6}: 1500 \mathrm{mg} ; B_{12}: 10 \mathrm{mg}$; Biotin: $50 \mathrm{mg}$; Choline chloride: $250000 \mathrm{mg}$; Pantothenic acid: $10000 \mathrm{mg}$; Nicotinic acid: $30000 \mathrm{mg}$; Folic acid: $1000 \mathrm{mg}$; Minerals: Mn: $60000 \mathrm{mg}$; Zn: $50000 \mathrm{mg}$; Fe: $30000 \mathrm{mg}$; $\mathrm{Cu}: 10000 \mathrm{mg}$; I: $1000 \mathrm{mg}$; Se: $100 \mathrm{mg}$ and Co: $100 \mathrm{mg}$. ** according to NRC (1994)

\section{Carcass characteristics:}

At the end of the experimental period (35 days of age), slaughter tests were performed using three chickens selected according to the average live body weight of each treatment. The percentage in relation to live weight of carcass, liver, heart, gizzard, giblets and edible parts were estimated as carcass characteristics.

\section{Ileum bacterial counts:}

Content of ileum were collected to determine the microbiological flora as follow: Total bacterial counts were determined as suggested by American Public Health Association (Marshall, 1992). Total lactic acid bacterial counts were determined according to De Man et al. (1960). Coliform bacteria were enumerated according to Marshall (1992). Salmonella viable count was enumerated according to Roberts et al. (1995).

\section{Economical traits:}

A production cost analysis and economical evaluation was carried out for all dietary treatments in an attempt to investigate effects of different feed additives inclusion on relative economic efficiency.

\section{Statistical Analysis:}

The statistical analysis was conducted using the general linear model (GLM) procedures of SAS (2004). Means were compared using Duncan's Multiple Rang test (Duncan, 1955) and level of significance was set at minimum of $(\mathrm{P} \leq 0.05)$. 
The statistical model was:

$\mathrm{Yij}=\mu+\mathrm{Ti}+\mathrm{eij}$

Where:

Yij = an observation of the parameter measured

$\mu \quad=$ an overall mean

$\mathrm{Ti}=$ effect of treatment (i: 1 to 5$)$

eij $=$ experimental random error

\section{RESULTS AND DISCUSSION}

\section{Growth performance:}

The mean values of live body weight (LBW), daily weight gain (DWG), daily feed intake (DFI) and feed conversion ratio (FCR) are shown in Tables (2 and 3).

Table (2): Effect of dietary treatments on live body weight (LBW) and daily weight gain (DWG).

\begin{tabular}{lcccccc}
\hline \multirow{2}{*}{ Item } & \multicolumn{7}{c}{ Experimental Treatment } & Sig. \\
\cline { 2 - 5 } & $\mathrm{T} 1$ & $\mathrm{~T} 2$ & $\mathrm{~T} 3$ & $\mathrm{~T} 4$ & $\mathrm{~T} 5$ & \\
\hline LBW (1 day) & 38.83 & 38.44 & 38.73 & 39.60 & 38.34 & $\mathrm{NS}$ \\
& \pm 0.01 & \pm 0.01 & \pm 0.01 & \pm 0.01 & \pm 0.01 & \\
LBW (14 days) & $335.01^{\mathrm{a}}$ & $315.01^{\mathrm{ab}}$ & $308.33^{\mathrm{b}}$ & $296.66^{\mathrm{b}}$ & $318.33^{\mathrm{ab}}$ & $*$ \\
& \pm 10.00 & \pm 5.77 & \pm 1.66 & \pm 9.27 & \pm 6.01 & \\
LBW (28 days) & 1337.41 & 1291.67 & 1273.52 & 1243.15 & 1261.67 & $\mathrm{NS}$ \\
& \pm 8.12 & \pm 21.66 & \pm 17.57 & \pm 8.23 & \pm 9.18 & \\
LBW (35 days) & 1859.58 & 1888.70 & 1883.38 & 1770.01 & 1814.82 & $\mathrm{NS}$ \\
& \pm 60.45 & \pm 29.62 & \pm 62.21 & \pm 25.01 & \pm 58.21 & \\
DWG (g) (0-14 days) & $21.16^{\mathrm{a}}$ & $19.75^{\mathrm{ab}}$ & $19.26^{\mathrm{b}}$ & $18.36^{\mathrm{b}}$ & $19.99^{\mathrm{ab}}$ & $*$ \\
& \pm 0.71 & \pm 0.41 & \pm 0.12 & \pm 0.66 & \pm 0.42 & \\
DWG (g) (15-28 days) & 71.60 & 69.76 & 68.94 & 67.61 & 67.38 & $\mathrm{NS}$ \\
& \pm 0.98 & \pm 1.13 & \pm 1.16 & \pm 2.78 & \pm 3.09 & \\
DWG (g) (29-35 days) & 74.59 & 85.29 & 87.12 & 75.26 & 79.02 & NS \\
& \pm 9.47 & \pm 1.91 & \pm 6.49 & \pm 3.37 & \pm 5.79 & \\
DWG (g) (0-35 days) & 52.02 & 52.86 & 52.70 & 49.44 & 50.75 & NS \\
\hline
\end{tabular}

$a, \overline{b \text { Means within the same row with different superscripts are significantly different. Sig. }=\text { Significance, } *(P \leq 0.05)}$ NS: Non-Significant.

T1: basal diet, T2: basal diet + Sodium di-formate $2 \mathrm{~g} / \mathrm{Kg}$, T3: basal diet + Formic acid $2 \mathrm{ml} \mathrm{Kg}$, T4: basal diet + Lactobacillus acidophilus $1 \mathrm{~g} / \mathrm{Kg}$, T5: basal diet + Lactic acid bacteria with enzymes $1 \mathrm{~g} / \mathrm{Kg}$.

The LBW and DWG of broiler chicks as affected by dietary treatments are illustrated in Table (2). It is worth to note that the chicks fed T3 and T4 during studied periods (0-14 and 15-28 days) reflected the lowest results in both live body weight and daily weight gain compared with the other treatments (T1, T2 and T5). However, during the starting period (0-14 days), chicks of T3 and T4 decreased by 8.94 and $13.19 \%$ compared with that fed control diets (T1), (19.26 and 18.36 versus $21.15 \mathrm{~g}$ ) for DWG. Besides, the differences between treatments were significant.

Moreover, during growing period (15-28 days), chicks of T4 and T5 decreased by 5.57 and 5.89\% (67.61 and 67.38 versus $71.60 \mathrm{~g}$, respectively), however, the differences failed to be significant. Also, during finishing period (29-35 days) chicks fed T2 and T3 diets gained more weight and gave the best figures than those fed other dietary treatments and the corresponding values were 85.29 (T2) and $87.12 \mathrm{~g}$ (T3) versus 74.59 (T1), 75.26 (T4) and $79.02 \mathrm{~g}$ (T5), respectively, the differences were statistically not significant. These results agree with the results of Abdelaziz (2015), El-Faham et al. (2014) and Higgins et al. (2008).

Similar observation was reported by Loddi et al. (2000) who stated that, there were no beneficial effects of probiotic supplementation and negatively influenced body weight and weight gain of broilers from either 1 to 21 , or 1 to 42 days of age. On the other hand, these findings were in contrast with the results obtained by Nematallah et al. (2015), Awad et al. (2013), Nagla et al. (2012) and Tollba et al. (2004) who concluded that 
adding the tested biological additives or different types of organic acids increased significantly live body weight and weight gain than control group.

Data in Table (3) indicated that, during starting period, feed intake per chick (g/ d) and feed conversion ratios were significantly affected by dietary treatments.

Table (3): Effect of dietary treatments on daily feed intake (DFI) and feed conversion ratio (FCR).

\begin{tabular}{lcccccc}
\hline \multirow{2}{*}{ Item } & \multicolumn{7}{c}{ Experimental Treatment } & Sig. \\
\cline { 2 - 6 } DFI (g) (0-14 days) & $\mathrm{T} 1$ & $\mathrm{~T} 2$ & $\mathrm{~T} 3$ & $\mathrm{~T} 4$ & $\mathrm{~T} 5$ & \\
& $26.75^{\mathrm{b}}$ & $26.88^{\mathrm{b}}$ & $26.42^{\mathrm{b}}$ & $25.25^{\mathrm{b}}$ & $29.43^{\mathrm{a}}$ & $* *$ \\
DFI (g) (15-28 days) & \pm 0.66 & \pm 0.24 & \pm 0.62 & \pm 0.83 & \pm 0.31 & \\
& 115.88 & 109.52 & 110.95 & 112.54 & 106.67 & $\mathrm{NS}$ \\
DFI (g) (29-35 days) & \pm 2.64 & \pm 1.34 & \pm 3.33 & \pm 7.07 & \pm 2.37 & \\
& 136.02 & 139.62 & 140.78 & 138.01 & 140.82 & $\mathrm{NS}$ \\
DFI (g) (0-35 days) & \pm 4.13 & \pm 8.05 & \pm 6.34 & \pm 10.98 & \pm 3.67 & \\
& 84.25 & 82.48 & 83.10 & 82.72 & 82.61 & $\mathrm{NS}$ \\
FCR (0-14 days) & \pm 0.30 & \pm 1.04 & \pm 2.79 & \pm 2.53 & \pm 1.36 & \\
& $1.26^{\mathrm{c}}$ & $1.36^{\mathrm{bc}}$ & $1.37^{\mathrm{b}}$ & $1.38^{\mathrm{ab}}$ & $1.47^{\mathrm{a}}$ & $*$ \\
FCR (15-28 days) & \pm 0.04 & \pm 0.03 & \pm 0.02 & \pm 0.01 & \pm 0.03 & \\
& 1.62 & 1.57 & 1.62 & 1.66 & 1.59 & $\mathrm{NS}$ \\
FCR (29-35 days) & \pm 0.05 & \pm 0.04 & \pm 0.02 & \pm 0.04 & \pm 0.09 & \\
& 1.89 & 1.63 & 1.62 & 1.82 & 1.80 & NS \\
FCR (0-35 days) & \pm 0.28 & \pm 0.10 & \pm 0.04 & \pm 0.07 & \pm 0.13 & \\
& 1.62 & 1.56 & 1.57 & 1.67 & 1.63 & NS \\
\hline
\end{tabular}

$a, b, c$ Means within the same row with different superscripts are significantly different. Sig. = Significance, ** $(P \leq 0.01), *(P \leq 0.05)$. NS: Non-Significant.

T1: basal diet, T2: basal diet + Sodium di-formate $2 \mathrm{~g} / \mathrm{Kg}$, T3: basal diet + Formic acid $2 \mathrm{ml} \mathrm{Kg}$, T4: basal diet + Lactobacillus acidophilus $1 \mathrm{~g} / \mathrm{Kg}$, T5: basal diet + Lactic acid bacteria with enzymes $1 \mathrm{~g} / \mathrm{Kg}$.

The addition of lactic acid bacteria with enzymes to basal diet (T5) led chicks to consume significantly $(\mathrm{P}<0.01)$ more feed than other dietary treatments $(\mathrm{T} 1-4)$ and FCR showed the same trend and the corresponding values for DFI ranged between 25.25 and $29.43 \mathrm{~g}$, while FCR ranged between 1.26 and 1.47 and showed significant difference, as shown in Table (3).

The effect of different dietary treatments T1: T5 on DFI and FCR during growing, finishing or whole experiment period showed no significant differences and DFI ( $0-35$ days) ranged between 82.48 and $84.25 \mathrm{~g}$ and chicks fed control diet (T1) gave the highest figure while chicks fed (T2) diet had the lowest figures and differences among treatment were insignificant.

In the same order, FCR (0-35 days) showed the same trend since chicks fed (T2) diet were more efficient in converting their food into body weight gain compared with those fed control diets (T1). The corresponding figures were 1.56 versus 1.62 , without any significant differences. The better performance of broilers fed with organic acids or their salts can be explained in many ways, improved nutrient utilization, enlarged gut surface and counteract potential pathogenic bacteria (Papatsirous and Billinis, 2012), Lückstädt and Mellor (2011) and Asmaa and Hayam (2017). Oppositely, these results disagree with those of Vale et al. (2004), Leeson et al. (2005) and Gunal et al. (2006) who reported that supplementation of an organic acid or organic acid salt did not have any effect on LBW or FCR. In addition, Miller (1987) reported that when chicks were housed in a clean environment, organic acids did not have any effect on performance.

\section{Protein conversion ratio (PCR) and energy conversion ratio (ECR):}

Results of Table (4) showed a significant effect on PCR and ECR for broiler chicks due to feed additives supplementation to broiler diets at starting period (0-14 days).

At 14 days, chicks fed control diets (T1) reflected the best PCR and ECR compared with other treatments (T2: T5). However, PCR decreased by $13.8 \%$ ( 0.29 versus 0.33 ) compared with that fed T5 diets and ECR showed similar trend $16.3 \%$ (3.86 versus 4.49). Besides, the differences between the two treatments were significant. While, PCR and ECR indicated insignificant differences between birds fed different dietary 
treatments (T2: T5) compared with those fed control diets (T1) at growing, finishing and whole experimental period. For the whole experimental period, the best PCR (0.32) and ECR (4.81) were detected for the chicks fed T2 diets. On the other hand, the worst PCR (0.34) and ECR (5.12) were found in chicks fed T4 diets, and the differences between treatments failed to be significant (Table 4).

Table (4): Effect of dietary treatments on protein conversion ratio (PCR) and energy conversion ratio (ECR).

\begin{tabular}{|c|c|c|c|c|c|c|}
\hline \multirow{2}{*}{ Item } & \multicolumn{5}{|c|}{ Experimental Treatment } & \multirow{2}{*}{ Sig. } \\
\hline & T1 & $\mathrm{T} 2$ & T3 & $\mathrm{T} 4$ & T5 & \\
\hline $\mathrm{PCR}^{1}$ (g protein/ & $0.29^{b}$ & $0.32^{\mathrm{ab}}$ & $0.32^{\mathrm{ab}}$ & $0.31^{\mathrm{ab}}$ & $0.33^{\mathrm{a}}$ & * \\
\hline g gain) (0-14 days) & \pm 0.01 & \pm 0.01 & \pm 0.01 & \pm 0.01 & \pm 0.01 & \\
\hline PCR (g protein/ & 0.34 & 0.33 & 0.34 & 0.35 & 0.34 & NS \\
\hline g gain) (15-28 days) & \pm 0.01 & \pm 0.01 & \pm 0.01 & \pm 0.01 & \pm 0.01 & NS \\
\hline PCR (g protein/ & 0.36 & 0.31 & 0.31 & 0.35 & 0.34 & \\
\hline g gain) (29-35 days) & \pm 0.05 & \pm 0.02 & \pm 0.01 & \pm 0.01 & \pm 0.02 & NS \\
\hline PCR (g protein/ & 0.33 & 0.32 & 0.32 & 0.34 & 0.34 & \\
\hline g gain) (0-35 days) & \pm 0.01 & \pm 0.01 & \pm 0.01 & \pm 0.01 & \pm 0.01 & NS \\
\hline $\mathrm{ECR}^{2}$ (Kcal/g gain) $(0-$ & $3.86^{\mathrm{b}}$ & $4.15^{\mathrm{b}}$ & $4.18^{\mathrm{ab}}$ & $4.19^{\mathrm{ab}}$ & $4.49^{\mathrm{a}}$ & * \\
\hline 14 days) & \pm 0.13 & \pm 0.12 & \pm 0.08 & \pm 0.03 & \pm 0.10 & \\
\hline ECR (Kcal/ g gain) (15- & 5.12 & 4.96 & 5.08 & 5.25 & 5.02 & \\
\hline 28 days) & \pm 0.18 & \pm 0.14 & \pm 0.06 & \pm 0.15 & \pm 0.29 & NS \\
\hline ECR (Kcal/g gain) (29- & 6.13 & 5.31 & 5.25 & 5.92 & 5.83 & NS \\
\hline 35 days) & \pm 0.92 & \pm 0.33 & \pm 0.15 & \pm 0.25 & \pm 0.47 & IVS \\
\hline ECR (Kcal/ g gain) (0- & 5.04 & 4.81 & 4.84 & 5.12 & 5.11 & NS \\
\hline 35 days) & \pm 0.29 & \pm 0.07 & \pm 0.01 & \pm 0.12 & \pm 0.18 & IV S \\
\hline
\end{tabular}

$a, b$ Means within the same row with different superscripts are significantly different. Sig. $=$ Significance, ${ }^{*}(P \leq 0.05)$. NS: Non-Significant.

${ }^{I}$ Calculated as $(F C R *$ Crude Protein \%) / 100

${ }^{2}$ Calculated as $(F C R * M E$ Kcal/ Kg diet $) / 1000$

T1: basal diet, T2: basal diet + Sodium di-formate $2 \mathrm{~g} / \mathrm{Kg}$, T3: basal diet + Formic acid $2 \mathrm{ml}$ Kg, T4: basal diet + Lactobacillus acidophilus $1 \mathrm{~g} / \mathrm{Kg}$, T5: basal diet + Lactic acid bacteria with enzymes $1 \mathrm{~g} / \mathrm{Kg}$.

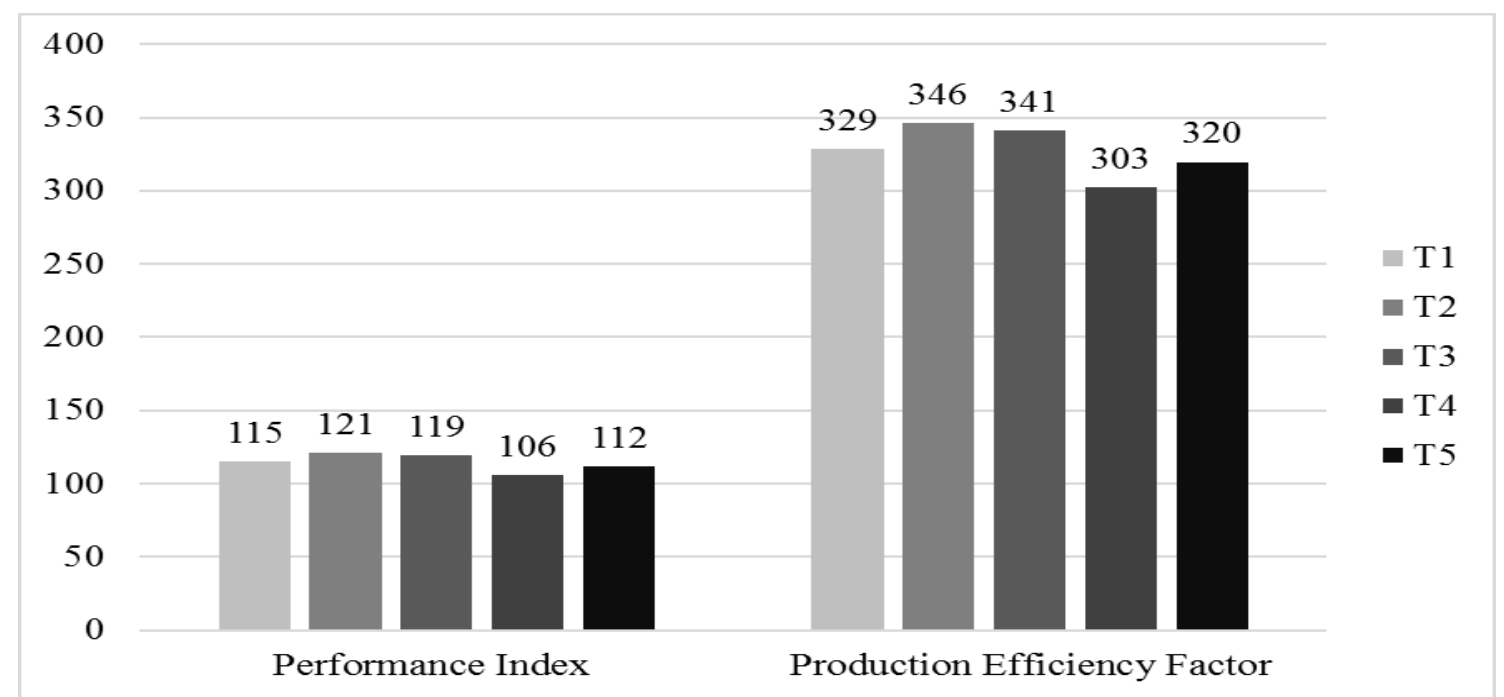

Figure (1): Effect of different dietary treatments on performance index (PI) and production efficiency factor (PEF).

Performance Index: North and Bell (1981), Production Efficiency Factor: Emmert (2000).

T1: basal diet, T2: basal diet + Sodium di-formate $2 \mathrm{~g} / \mathrm{Kg}$, T3: basal diet + Formic acid $2 \mathrm{ml} / \mathrm{Kg}$, T4: basal diet + Lactobacillus acidophilus $1 \mathrm{~g} / \mathrm{Kg}$, T5: basal diet + Lactic acid bacteria with enzymes $1 \mathrm{~g} / \mathrm{Kg}$. 
Numerous reports, have demonstrated how including organic acids or their salts in broiler diets has beneficial effects on performance by lowering bacterial pathogen load and improving nutrient digestibility and decreased level of toxic bacterial metabolites as a result of less bacterial fermentation, causing an improvement in the protein and energy digestibility thus enhancing the weight gain and performance (Ghazalah et al. 2011 and Asmaa and Hayam, 2017).

\section{Performance index (PI) and production efficiency factor (PEF):}

Results of PI and PEF as affected by different dietary treatments throughout the whole experimental period (0-35 days of age) are presented in Figure (1). The obtained data showed that there were insignificant differences in PI and PEF values among treatments and broiler chicks fed T2 and T3 diets reflected the highest PI and PEF compared with control group. The corresponding figures were 121 and $119 \%$ versus 115 $\%$ for PI and 346 and $341 \%$ versus $329 \%$ for PEF with insignificant differences between treatments.

In the same order, broiler chicks fed T4 and T5 diets reflected the lowest figures for (PI and PEF) compared with other dietary treatments and the corresponding figures being (106 and 303\% or 112 and $320 \%$ ), respectively and differences between treatments were insignificant. These results agree with those reported by Abdel-Mageed (2012) in Japanese quail and Chaveerach et al. (2004) in broiler chicks as they reported that PI values were not affected by organic acids addition to diets.

These findings are in contrast with the results obtained by Ghazalah et al. (2011) in broiler chicks and Asmaa and Hayam (2017) in ducks, as they concluded that, the addition of organic acids to diets could improve the production index as compared to control group.

\section{Blood plasma parameters:}

Results concerning plasma total protein (TP), albumin (Alb), globulin (Glo), (Alb/ Glo) ratio, creatinine (Cre), urea (Ure) and uric acid (Ua) concentrations are shown in Table (5).

There were no significant differences in Glo, Alb/ Glo ratio, Cre and Ure among different treatments. Supplementing sodium diformate, formic acid or lactobacillus acidophilus to broiler diets (T2, T3 and T4) gave similar blood plasma parameters in comparison to control group (T1), except (Ua) and the highest values were found in T3 and T4, respectively than other treatments (T2 and T5) and control group (T1). The differences among treatments were significant in most cases. Moreover, chickens fed diets containing sodium diformate (T2) showed the highest (TP and Alb) concentrations (3.97 and $2.06 \mathrm{~g} / \mathrm{dL}$ ), respectively. While, birds fed (T5 diets) had the lowest figures being ( 2.74 and $1.53 \mathrm{~g} / \mathrm{dL})$, respectively.

Table (5): Effect of dietary treatments on some blood plasma parameters.

\begin{tabular}{|c|c|c|c|c|c|c|}
\hline \multirow{2}{*}{ Item } & \multicolumn{5}{|c|}{ Experimental Treatment } & \multirow{2}{*}{ Sig. } \\
\hline & $\mathrm{T} 1$ & $\mathrm{~T} 2$ & $\mathrm{~T} 3$ & $\mathrm{~T} 4$ & T5 & \\
\hline \multirow{2}{*}{ Total Protein g / dL } & $3.75^{\mathrm{a}}$ & $3.97^{\mathrm{a}}$ & $3.73^{\mathrm{a}}$ & $3.09^{\mathrm{ab}}$ & $2.74^{\mathrm{b}}$ & \multirow{2}{*}{$*$} \\
\hline & \pm 0.37 & \pm 0.23 & \pm 0.21 & \pm 0.10 & \pm 0.30 & \\
\hline \multirow{2}{*}{ Albumin g / dL } & $1.90^{\mathrm{a}}$ & $2.06^{\mathrm{a}}$ & $1.98^{\mathrm{a}}$ & $1.89^{\mathrm{a}}$ & $1.53^{\mathrm{b}}$ & \multirow{2}{*}{$* *$} \\
\hline & \pm 0.09 & \pm 0.06 & \pm 0.05 & \pm 0.05 & \pm 0.08 & \\
\hline \multirow{2}{*}{ Globulin g / dL } & 1.85 & 1.91 & 1.74 & 1.20 & 1.21 & \multirow{2}{*}{ NS } \\
\hline & \pm 0.28 & \pm 0.19 & \pm 0.17 & \pm 0.11 & \pm 0.32 & \\
\hline \multirow{2}{*}{ Albumin/ Globulin ratio } & 1.06 & 1.10 & 1.15 & 1.61 & 1.49 & \multirow{2}{*}{ NS } \\
\hline & \pm 0.12 & \pm 0.11 & \pm 0.10 & \pm 0.18 & \pm 0.42 & \\
\hline \multirow{2}{*}{ Creatinine $\mathrm{mg} / \mathrm{dL}$} & 0.47 & 0.47 & 0.52 & 0.46 & 0.43 & \multirow{2}{*}{ NS } \\
\hline & \pm 0.03 & \pm 0.03 & \pm 0.09 & \pm 0.02 & \pm 0.04 & \\
\hline \multirow{2}{*}{ Urea mg / dL } & 7.10 & 6.93 & 7.50 & 8.76 & 7.56 & \multirow{2}{*}{ NS } \\
\hline & \pm 0.78 & \pm 0.73 & \pm 0.60 & \pm 0.52 & \pm 1.61 & \\
\hline \multirow{2}{*}{ Uric Acid mg / dL } & $4.38^{\mathrm{b}}$ & $4.84^{\mathrm{ab}}$ & $6.41^{\mathrm{a}}$ & $6.31^{\mathrm{a}}$ & $4.53^{b}$ & \multirow{2}{*}{$*$} \\
\hline & \pm 0.16 & \pm 0.43 & \pm 0.38 & \pm 0.80 & \pm 0.53 & \\
\hline
\end{tabular}


The differences among treatments were significant. The obtained data disagree with those reported by many investigators (Kalavathy et al., 2003; Abdel-Azeem and Hamid, 2006; Abdalla et al., 2008; Nematallah et al., 2015). They concluded that there were no significant differences in blood parameters (TP, Alb and Glo) due to probiotic supplementation. On the other hand, Tollba et al. (2004) found that adding probiotic additives to broiler diets increase plasma (TP, Alb and Glo) compared to control group.

\section{Carcass characteristics:}

No significant differences were found between birds fed the control diet and all treatments in all carcass characteristics values (Table 6). The control diet recorded the highest values of dressed carcass $\%$ and total edible parts \% (Hot carcass weight + giblets weight) percentage being $(71.06 \%$ and $75.27 \%)$, respectively. While, chickens fed formic acid diets (T3) recorded the lowest values $(68.15 \%$ and $72.34 \%$ ), respectively. Besides, the differences between treatments were insignificant.

Obtained results agree with those reported by Nematallah et al. (2015); Abdel-Azeem and Hamid (2006) and El-Yamny and Fadel (2004) who reported that growth promoters had no significant differences among all groups in carcass weight and dressing percentage. These findings are in contrast with the results obtained by Abdel-Mageed (2012) in Japanese quail and Leeson et al. (2005) in broiler chickens. They concluded that, feeding butyric acid supplemented diets significantly increased carcass parameters.

Table (6): Effect of dietary treatments on some carcass traits.

\begin{tabular}{|c|c|c|c|c|c|c|}
\hline \multirow{2}{*}{ Item } & \multicolumn{5}{|c|}{ Experimental Treatment } & \multirow{2}{*}{ Sig. } \\
\hline & $\mathrm{T} 1$ & $\mathrm{~T} 2$ & $\mathrm{~T} 3$ & $\mathrm{~T} 4$ & T5 & \\
\hline \multirow{2}{*}{ Dressed carcass $\%$} & 71.06 & 70.14 & 68.15 & 68.67 & 68.60 & \multirow{2}{*}{ NS } \\
\hline & \pm 1.23 & \pm 0.14 & \pm 0.21 & \pm 1.04 & \pm 0.67 & \\
\hline \multirow{2}{*}{ Liver \% } & 2.41 & 2.19 & 2.24 & 2.24 & 2.42 & \multirow{2}{*}{ NS } \\
\hline & \pm 0.12 & \pm 0.20 & \pm 0.17 & \pm 0.15 & \pm 0.17 & \\
\hline \multirow{2}{*}{ Gizzard \% } & $1.27^{\mathrm{ab}}$ & 1.45 & 1.35 & $1.33^{\mathrm{ab}}$ & 1.34 & \multirow{2}{*}{ NS } \\
\hline & \pm 0.06 & \pm 0.13 & \pm 0.19 & \pm 0.14 & \pm 0.03 & \\
\hline \multirow{2}{*}{ Heart \% } & 0.52 & 0.56 & 0.59 & 0.54 & 0.61 & \multirow{2}{*}{ NS } \\
\hline & \pm 0.04 & \pm 0.03 & \pm 0.02 & \pm 0.02 & \pm 0.05 & \\
\hline \multirow{2}{*}{ Giblets $^{*} \%$} & 4.20 & 4.20 & 4.19 & 4.12 & 4.37 & \multirow{2}{*}{ NS } \\
\hline & \pm 0.16 & \pm 0.24 & \pm 0.24 & \pm 0.18 & \pm 0.17 & \\
\hline \multirow{2}{*}{ Total edible parts $\%$} & 75.27 & 74.34 & 72.34 & 72.79 & 72.97 & \multirow{2}{*}{ NS } \\
\hline & \pm 1.39 & \pm 0.38 & \pm 0.32 & \pm 1.07 & \pm 0.69 & \\
\hline
\end{tabular}

\section{Ileum bacterial counts:}

Ileum bacterial counts in broilers at 35 days of age are presented in Table (7). Data indicated that all feed additives used, in the current study tended to increase values of total bacteria count and lactic acid bacteria. Birds fed control diet (T1), showed the lowest total and lactic acid bacteria counts, $(65,000$ and 165,000 CFU). While, birds fed (T4 or T5) diets, had higher figures, being 13, 437,500 and 3,807,500 for total count and $1,237,500$ and 1,302,500 CFU for lactic acid bacteria count, respectively.

Table (7): Effect of different dietary treatments on some intestinal microbiology parameters.

\begin{tabular}{lccccc}
\hline \multirow{2}{*}{ Item } & \multicolumn{5}{c}{ Experimental Treatment } \\
\cline { 2 - 5 } & $\mathrm{T} 1$ & $\mathrm{~T} 2$ & $\mathrm{~T} 3$ & $\mathrm{~T} 4$ & $\mathrm{~T} 5$ \\
\hline Total Count & 65000 & 4395000 & 1245000 & 13437500 & 3807500 \\
Lactic Acid bacteria Count & 165000 & 849000 & 780000 & 1237500 & 1302500 \\
Salmonella Count & 1000 & 100 & 115 & 210 & 500 \\
Coliform Count & 3000 & 385 & 402 & 1625 & 261
\end{tabular}

T1: basal diet, T2: basal diet + Sodium di-formate $2 \mathrm{~g} / \mathrm{Kg}$, T3: basal diet + Formic acid $2 \mathrm{ml} / \mathrm{Kg}$, T4: basal diet + Lactobacillus acidophilus $1 \mathrm{~g} / \mathrm{Kg}$, T5: basal diet + Lactic acid bacteria with enzymes $1 \mathrm{~g} / \mathrm{Kg}$. 
On the other hand, the values of coli-form and salmonella counts were decreased in comparison with the control group. Birds fed T5 or T2 diets recorded lower counts, respectively. The present results agreed with that of previous authors (Chaveerach et al., 2002; Heres et al., 2003; Mountzouris et al., 2007). Additionally, Lückstädt and Theobald (2009) and Lückstädt et al. (2014), reported that dietary probiotic, organic acids and their salts reduced impact of pathogenic bacteria in broiler chicken, with improved gut microflora and bird performance.

In general, the biological additives or different types of organic acids and their salts improve protein and energy digestibility by reducing microbial competition with the host for nutrients and endogenous nitrogen losses and lowering the incidence of sub-clinical infections (Table 7). Also, reducing the production of ammonia as indirect effect and other growth suppressing microbial metabolites. Probably these could be explaining the role to improve feed utilization which leading to better performance in broilers.

\section{Economic traits:}

Calculations of feeding economic efficiency were carried out according to the prices of feed ingredients, additives and live body weight during year 2017 (the experimental time) as summarized in Table (8).

Feeding relative economic efficiency values of broiler chickens were improved by 105.49 and $104.77 \%$ for the groups fed diets contained sodium diformate (T2) and formic acid (T3), respectively as compared to the control group (100\%) during overall period (0-35 days). On the other hand, chickens fed diets contained probiotic (T4 and T5) had the lowest corresponding values, being 86.55 and $93.58 \%$, respectively.

Table (8): Effect of dietary treatments on some economic traits.

\begin{tabular}{lccccc}
\hline \multirow{2}{*}{ Item } & \multicolumn{5}{c}{ Experimental Treatments } \\
\cline { 2 - 5 } & $\mathrm{T} 1$ & $\mathrm{~T} 2$ & $\mathrm{~T} 3$ & $\mathrm{~T} 4$ & $\mathrm{~T}$ \\
\hline Feed Cost / Bird (LE) & 18.79 & 18.74 & 18.71 & 18.62 & 18.68 \\
Total Cost $^{1}$ / Bird (LE) & 31.79 & 31.74 & 31.71 & 31.62 & 31.68 \\
Total Return $^{2}$ Bird (LE) & 46.49 & 47.22 & 47.08 & 44.25 & 45.37 \\
Net Return / Bird (LE) $^{\text {Economic Efficiency }}{ }^{3}$ & 14.70 & 15.47 & 15.38 & 12.63 & 13.68 \\
Relative Economic Efficiency $^{4}$ & 0.46 & 0.49 & 0.48 & 0.40 & 0.43 \\
\hline
\end{tabular}

${ }_{1}^{1}$ Total cost $=($ feed cost + price of one-day live chicks + incidental costs $) ;$ L.E.: Egyptian Pound

${ }^{2}$ According to the local price of Kg sold live birds which was $25.00 \mathrm{L.E}$.

${ }^{3}$ Economic efficiency $=$ net return/total feed cost. Whereas net revenue $=$ total return - total feed cost.

${ }^{4}$ Assuming that the relative economic efficiency of control group equals 100.

T1: basal diet, T2: basal diet + Sodium di-formate $2 \mathrm{~g} / \mathrm{Kg}$, T3: basal diet + Formic acid $2 \mathrm{ml} \mathrm{Kg}$, T4: basal diet + Lactobacillus acidophilus $1 \mathrm{~g} / \mathrm{Kg}$, T5: basal diet + Lactic acid bacteria with enzymes $1 \mathrm{~g} / \mathrm{Kg}$.

These results agreed with those of Abdelaziz (2015) who indicated that, sodium diformate as feed additive could be included at different levels in broiler diets without any adverse effect on productive performance as well as to economical feed costs.

In addition, El-Faham et al. (2014) found that chicks fed diets contained probiotic had the lowest economical and relative efficiency as compared with control group. These results are in contrast with those of Qota et al. (2002) who reported that probiotic supplementation insignificantly affected on the economic efficiency of broilers up to 42 days of age. On the other hand, Soliman et al. (2003) found that the inclusion of probiotic or herbal feed additives in broiler diets results in least feed cost/ $\mathrm{kg}$ gain and the highest percent of economic efficiency as compared with control diet.

Accordingly, it could be concluded that, supplementation of basal diets with formic acid or its sodium salt, enhanced performance and economic efficiency of broiler chickens

\section{REFERENCES}

Abdalla, E.; A. Soher; Y. Saleh; S. Mary and A. Hathout (2008). Probiotic bacteria as a tool to produce high quality and safe Ras cheese. Egyptian Journal of dairy Science, 36: 97-109. 


\section{El-Faham et al.}

Abdel-Azeem, F. and A.A. Hamid (2006). Using barley radical with yeast cultures supplementation in broilers diets. Egypt. Poult. Sci., 26(1): 179-206.

Abdelaziz, M.A.M. (2015). Effect of phosphorus restriction in presence of organic acid salt on bone quality and mineral digestibility of broilers. Egypt. Poult. Sci. 35: 961-977.

Abdelhady, A.Y.M.; H.A. El-Alaily; S.A. Ibrahim and M.A.M. Abdelaziz (2015). Effect of using sodium formate with restricted calcium and phosphorus on broiler performance and gut health. Egypt. J. Nutr. and feeds, 18(2) special Issue: 431-441.

Abdel-Mageed, M.A.A. (2012). Effect of using organic acids on performance of Japanese quail fed optimal and sub-optimal energy and protein levels. 2-Butyric acid. Egypt. Poult. Sci., 32(1): 625-644.

Abe, F.; N. Ishibashi and I. Shimamura (1995). Effect of administration of Bifidbacteria and Lactic acid bacteria to newborn calves and piglets. J. Dairy Sci. 78: 2838-2846.

Asmaa, Sh. Elnaggar and Hayam, M.A. Abo El-Maaty (2017). Impact of using organic acids on growth performance, blood biochemical and hematological traits and immune response of ducks (Cairina maschata). Egypt. Poult. Sci., 37(11): 907-925.

Awad, A.L.; A.I.A. Ghonim; M.H.A. Fatouh and M.F. Soliman (2013). Effect of supplementing Some growth promoters to duckling diets on growth performance and carcass traits under summer condition. Egypt Poult. Sci. 33: 371-391.

Chaveerach, P.; D.A. Keuzenkamp, H.A. Urlings; L.J. Lipman and F. van Knapen (2002). In vitro study on the effect of organic acids on Campylobacter jejuni/coli populations in mixtures of water and feed. Poult. Sci., 81: 621-628.

Chaveerach, P.; D.A. Keuzenkamp, L.J. Lipman and F. Van Knapen (2004). Effect of organic acids in during water for young broilers on campylobacter infection volatile fatty acid production, gut microflora and histological cell changes. Poult. Sci., 83: 330-334.

Das, L.; E. Bhaumik; U. Raychaudhuri and R. Chakraborty (2012). Role of nutraceuticals in human health. J. of food Sci. Tech. 49: 173-183.

De Man, J.C.; M. Rogosa and M.E.; Sharp (1960). A medium for cultivation of lactobacilli. J. Appl. Bacteriol, 23: 130.

Desai, D.; D. Pantwardhan and A. Ranade (2007). Acidifiers in poultry production. Nottingham Univ., Press Nothingham 63-69.

Duncan, D.B. (1955). Multiple ranges and multiple F test. Biometrics, 11: 1-42.

El-Faham A.; N.G. Ali and H.M. El-Maaty (2014). Effect of using some natural feed additives to substitute antibiotic growth promoters on performance and blood parameters of broilers. Egypt Poultry Science, 34: 735-750.

El-Yamny, A.T. and M. Fadel (2004). The influence of supplemented fungi or active yeast as growth promoter for diets of growing Japanese quail on the performance, metabolic responses and economic efficiency. Egypt. Poult. Sci., 24: 963-976.

Emmert, J. (2000). Efficiency of phase feeding in broilers. Proceeding, California Animal Nutrition Conference. Fresno California, USA.

Ghazalah A.A.; A.M. Atta; Kout Elkloub, M.EL. Moustafa and Riry F.H. Shata (2011). Effect of dietary supplementation of organic acids on performance, nutrients digestibility and health of broiler chicks. Int. J. of Poult. Sci., 10: 176-184.

Gunal, M.; G. Yaylo; O. Kaya; N. Karahan and O. Sulak (2006). The effect of antibiotic growth promoter. Probiotic or organic acid supplementation on performance, intestinal microflora and tissue of broilers. Int. J. of Poult. Sci., 5(2): 149-155.

Hebeler, D.; S. Kulla and G. Amtsberg (2000). Influence of a formic acid-potassium formate complex on chyme composition as well as on the intestinal microflora of weaned piglets proceedings of the society of Nutrition Physiology 9: 63. 
Helen, B. and L. Christian (2010). Performance enhancement through the use of diformate in broiler. ADDCON company in Germany program publication.

Heres, L.; B. Engel; F. Van Knapen; F. De Jong; J.A. Wagenaar and H.A.P. Urlings (2003). Fermented liquid feed reduces susceptibility of broilers for Salmonella enteritidis. Poult. Sci., 82: 603-611.

Higgins, S.E.; J.P. Higgins; A.D. Wolfenden; S.N. Henderson; A. Torres-Rodriguez; G. Tellez and B. Hargis (2008). Evaluation of Lactobacillus-based probiotic culture for the reduction of Salmonella Enteritidis in neonatal broiler chicks. Poult. Sci., 87: 27-31

Huyghebaert, G.; R. Ducatelle and F. Van Immersed (2011). An update on alternatives to antimicrobial growth promoters for broilers. The Vet J. 187: 182-188.

Kalavathy, R.; N. Abdullah; S. Jalaludin and Y.W. Ho (2003). Effects of Lactobacillus cultures on growth performance, abdominal fat deposition, serum lipids and weight of organs of broiler chickens. Br. Poult. Sci., 44: 139-144.

Kim J.W.; J.H. Kim and D.Y. Kil (2015). Dietary organic acids for broiler chickens: a review. Rev. Colomb. Cienc. Pecu., 28: 109-123.

Leeson, S.; H. Namkung; M. Antongiovanni and E.H. Lee (2005). Effect of butyric acid on the performance and carcass yield of broiler chickens. Poult. Sci., 84: 1418-1422.

Loddi, M.M.; E. Gonzales; T.S. Takita; A.A. Mendes and R. de-O.Roca (2000). Effect of the use of probiotic and antibiotic on the performance and carcass quality of broilers. Revista-Brasileira de Zootecnia, 29: 1124-1131.

Lückstädt C. and S. Mellor (2011). The use of organic acids in animal nutrition with special focus on dietary potassium diformate under European and Austral-Asian Conditions. Recent Adv. Anim. Nutr. Aust.; 18: $123-130$.

Lückstädt, C. and P. Theobald (2009). Effect of a formic acid-sodium formate premixture on Salmonella, Campylobacter and further gut microbiota in broilers. Proceedings and Abstracts of the 17th European Symposium on Poultry Nutrition: 246.

Lückstädt, C.; N. Greiffenstein and R. Dari (2014). Effect of dietary sodium diformate in broilers on the productivity index against a positive control. Conference on International Research on Food Security. Prague, Czech Republic

Makled, M.N. (1991). The potentials of probiotic in poultry feed. A Review Proceesing 3rd Sci. Symp. for Animal, Poultry and Fish Nutrition, 11: 54-68. Kafre-Elshake, Egypt.

Marshall, R.T. (1992). Standard methods for the examination of dairy products. American Public Health Association (APHA), Washington, D.C., USA.

Miller, B.F. (1987). Acidified poultry diets and their implications for poultry industry. In: Biotechnology in the feed industry. Alltech Technical Publications, Kentucky, page: 199-209.

Mountzouris, K.; P. Tsirtsikos; E. Kalamara; S. Nitsch and G. Schatzmayr (2007). Evaluation of the efficacy of a probiotic containing Lactobacillus, Bifidobacterium, Enterococcus, and Pediococcus strains in promoting broiler performance and modulating cecal microflora composition and metabolic activities. Poult. Sci., 86: 309-317.

Nagla K. Soliman; Y.M. Abyoussef and Nevine B. Ghanem (2012). Improving broiler performance and feed efficiency by adding organic acid to broiler diets. Egypt. J. Nutri and Feeds 15(2): 393-404.

Neish, A.; T. Gewirtz; H. Zeng and A.V. Young (2000). Prokaryotic regulation of epithelial responses by inhibition of uniquitanation. Poult. Sci. 289: 1560-1563.

Nematallah, G.M. Ali; A.F. Abdel-Salam; G.M. El-Gendi; A.A. Radwan and Heba Allah E. Megahid (2015). Modulation of physiological and microbiological broiler state by some growth promoters. Egypt. Poult. Sci. 35: 591-608.

North, M.O. and D.D. Bell (1981). Breeder Management. In "Commercial Chicken Production Manual" 4th Ed., Van Nostrand Reinhold. New York, USA. 


\section{El-Faham et al.}

NRC (1994). National Research Council. Nutrient Requirements of Poultry 9th Ed. Composition of Poultry Feedstuffs National Academy Press, Washington, DC, USA. P.P. 61-75.

Panda, A.K..; S.V. Raju Rama; G. Shyam Sunder and M.R. Reddy (2009). Effect of graded levels of formic acid on gut microflora count, serum biochemical parameters, performance and carcass yield of broiler chickens. Indian, J. Anim. Sci. 79: 1165-1168.

Papatsirous V.G. and C. Billinis (2012). The prophylactic use of Acidifiers as antibacterial Agents in Swine. Book Edited by Varaprasad Bobbarala ISBN978- 953-51-0723-1, Published: 2012.

Qota, E.M.A.; El-Ghamry, A.A. and G.M. El-Mallah (2002). Nutritive value of soaked linseed cake as affected by phytase, biogen supplementation or formulating diets based on available amino acids on broilers performance. Egypt. Poult. Sci., 22(II): 461-475.

Roberts, D.; W. Hooper and M. Green Wood (1995). Practical food microbiology, Public Health Laboratory Service, London, UK.

SAS (2004). SAS procedure guide Version 6. 12th Ed. SAS institute Inc. Cary, NC and U.C.A.

Seleem, T.S.T.; M.A.F. El-Manylawi, Y.M. Ragab and I.I. Omara (2011). Mature California rabbit performance as affected by prebiotic or/ and probiotics in drinking water. Egypt. J. Nutr. and Feeds, 14(2): 239-250.

Selle, P.H.; K.H. Huang and W.I. Muir (2004). Effects of potassium diformate inclusion in broiler diets on growth performance and nutrient utilization. Proceedings Aust. Poult. Sci. Symposium: 55-58.

Singer, R.S. and C.1. Hofacre (2006). Potential impacts of antibiotic use in poultry production. Avian Diseases 50: 161-172.

Soliman, A.Z.M., M.A. Ali and Z.M.A. Abdo, (2003). Effect of marjoram,bactiracin and active yeast as feed additives on the performance and the microbial content of the broiler's intestinal tract. Egypt Poult.Sci. 23: 445-467.

Tollba, A.A.H.; M.M. Sabry and G.G. Medani (2004). Effect of microbial probiotics on performance of broiler chicks under normal or heat stress conditions. Egypt Poult. Sci. 24(II): 333-249.

Tottori, J.; R. Yamaguch; Y. Murakawa; M. Sato; K. Uchida and S. Tateyama (1997). The use of feed restriction for mortality control of chickens in broiler farms. Avian Disease 41: 433-437.

Vale, M.M.; J.F.M. Menten; S.C.D. Morais and M.M.A. Brainer (2004). Mixture of formic and propionic acid as additives in broiler feeds. Sci. Agric. Braz., 61(4): 371-375.

Vesna, T.; M. Lazarevic; Z. Sinovec and A. Tokic (2007). The influence of different feed additives to performances and immune response in broiler chicken. Acta Veter. 57: 217-229. 
التقييم الغذائى لحامض الفورميك وملحه و المنشطات الحيوية في علائق بلارى التسمين



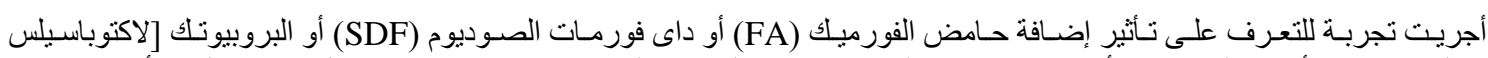

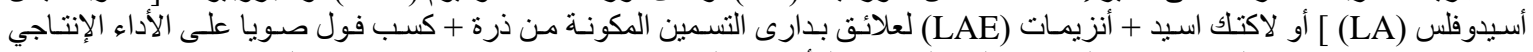

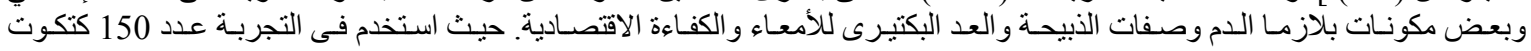

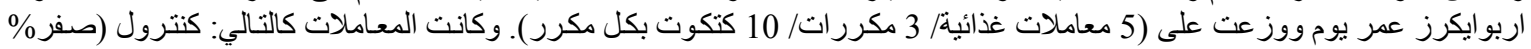



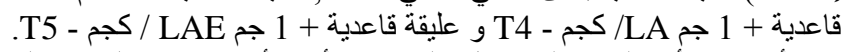

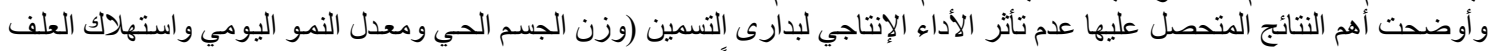

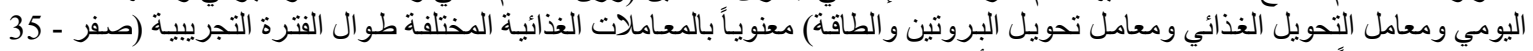

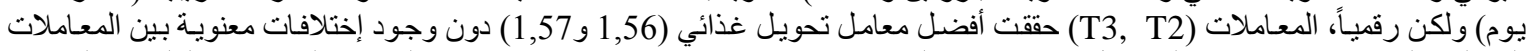

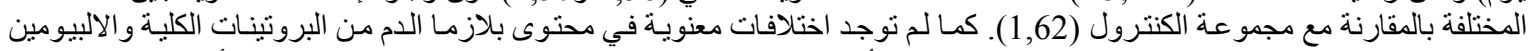

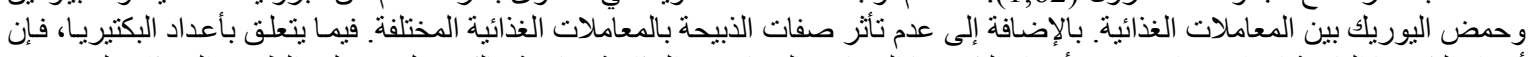

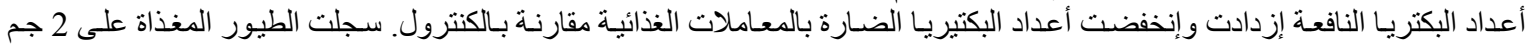

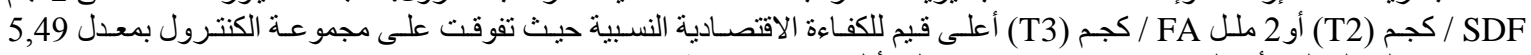

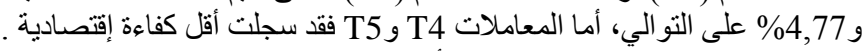

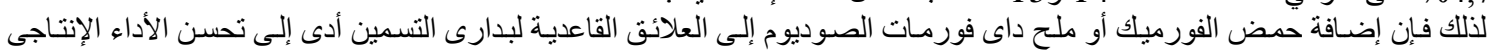

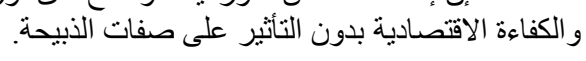

